ISSN 1392-3196 / e-ISSN 2335-8947

Zemdirbyste-Agriculture, vol. 102, No. 3 (2015), p. 289-296

DOI $10.13080 / \mathrm{z}-\mathrm{a} .2015 .102 .037$

\title{
Biologically active phenolic compounds in buckwheat, oats and winter spelt wheat
}

\author{
Ilona KERIENE ${ }^{1}$, Audronè MANKEVIČIENE ${ }^{1}$, Saulius BLIZNIKAS ${ }^{2}$, \\ Danutė JABLONSKYTĖ-RAŠČE் ${ }^{1}$, Stanislava MAIKŠTĖNIENË ${ }^{1}$, Rūta ČESNULEVIČIENE் ${ }^{1}$ \\ ${ }^{1}$ Lithuanian Research Centre for Agriculture and Forestry \\ Instituto 1, Akademija, Kèdainiai distr., Lithuania \\ E-mail: ilona.keriene@gmail.com
}

${ }^{2}$ Institute of Animal Science, Lithuanian University of Health Sciences

R. Žebenkos 12, Baisogala, Radviliškis distr., Lithuania

\begin{abstract}
The current study was aimed to determine the total phenolic content and antioxidant activity, rutin, quercetin and phenolic acids content in buckwheat, husked and common oats, winter spelt, winter and spring wheat grain with and without husks or glume, only husks or glume as well as to estimate phenolic compounds ratio and to compare their distribution between cereal grain and husks or glume. In this way to ascertain the losses of phenolic compounds in grain which will be used for food production. Total phenolic content and antioxidant activity were determined using the spectrophotometric method and individual phenolic compounds were estimated by high performance liquid chromatography.

The significantly highest total phenolic content $\left(10.2 \pm 1.6 \mathrm{mg} \mathrm{g}^{-1}\right.$ dry weight (d.w.) in grain with husks and 14.1 $\pm 2.0 \mathrm{mg} \mathrm{g}^{-1} \mathrm{~d}$.w. in husks), antioxidant activity (2-4 times), rutin concentration (from 146.5 to $406.3 \mu \mathrm{g} \mathrm{g}^{-1} \mathrm{~d}$.w.) and with a few exceptions hydroxybenzoic acids concentrations of all group of cereal samples (grain with and without husks or glume and only husks or glume) were established for buckwheat. Oats grain without husks or only husks were distinguished by the highest quercetin content, which was higher in husked oats samples (31-89 $\mu \mathrm{g} \mathrm{g}^{-1}$ d.w.). The highest total phenolic acids content was in common oats husks (882.4 $\mu \mathrm{g} \mathrm{g}^{-1} \mathrm{~d}$.w.). Ferulic and $p$-coumaric acid significantly $(P<0.01)$ predominated in all oats and wheat samples and accounted for about $70-90 \%$ of the total phenolic acids content. Syringic acid is characteristic of oats, winter spelt and winter wheat grain without glume and only glume. In all group of cereal samples sinapic acid predominated only in cereal grain with and without husks or glume. Significantly $(P<0.05)$ higher concentrations of vanillic, $p$-hydroxybenzoic, 3,4-dihydroxybenzoic, $p$-coumaric, ferulic acids, total phenolic content, antioxidant activity were quantified in cereal husks or glume compared with those in grain with and without husks or glume.
\end{abstract}

Key words: cereal grain, husks, phenolic acid, quercetin, rutin.

\section{Introduction}

Buckwheat, oats and wheat are recognized as a health food in many countries. Buckwheat is an important dietary product, since it contains proteins with high biological value and balanced amino acid composition (Vojtíšková et al., 2012). It is also abundant in the bioactive compounds characterised by antioxidant properties (Li et al., 2013). Buckwheat husks constitute $17-20 \%$ of the total buckwheat production and is removed by impact milling. Of all cereals, oats stand out by the highest nutritional value. The cultivation of common or husked oats has been on the increase recently because of their higher energy value compared with common oats (Biel et al., 2009). Moreover, they are major sources of dietary fibre in human diet, since practically the whole grain is used for food - bran and embryos are rarely removed (Skoglund, 2008). The research evidenced that spelt wheat produced $10 \%$ fewer productive stems compared with common wheat but the average values of protein and gluten for spelt wheat were higher than those for common wheat (Jablonskytė-Raščè et al., 2013).

The most important groups of bioactive compounds in cereals are phenolics (Balasundram et al., 2006). They are widely used in pharmaceutical industry as natural antioxidants (Gani et al., 2012; Sytar, 2014) and in food industry as the ones helping to preserve stability of processed products (Mackevic, 2010). The outer layer of grain has been shown to contain much higher levels of bioactive compounds. An important role is attributed to husks that protect grains from contamination with various pathogens (Čabarkapa et al., 2008). Phenolic compounds bioactivity in plants is significantly influenced by the composition of phenolic compounds. The most common phenolic compounds found in wholegrain cereals are phenolic acids and flavonoids. In 
buckwheat raw material flavonoid rutin accounts for a considerable part (Fabjan et al., 2003) and is included in the plant cellular structures (Lattanzio et al., 2006). Its content depends on the buckwheat phenological stage and displays therapeutic activity (Zielińska et al., 2010; Zhang et al., 2012). Quercetin is also characterised by a significant antioxidant activity (Dietrych-Szóstak, 2004); however, in buckwheat its content is several times lower than that of rutin (Fabjan et al., 2003). There is some data indicating that in low concentrations rutin and quercetin are also detected in oats fractions (Tong et al., 2014). Cereals contain a wide range of phenolic acids, which can be divided in two subgroups according to their structure: the hydroxybenzoic and the hydroxycinnamic acids. They are generally found esterified or bound to cell wall and only a minor fraction exists as free acids. The antioxidant activity is strongly dependent on phenolic acid structural features and related to the presence of hydroxyl function(s) in the aromatic structure (Teixeira et al., 2013). The avenanthramides, which are characteristic of oats only, are all composed of an anthranilic acid part and a cinnamic acid part, where the substitution pattern on the two parts is what distinguishes the different avenanthramides from each other (Skoglund, 2008; Mackevic, 2010). The total concentrations of avenanthramides in oats grains are in the range 2-289 $\mathrm{mg} \mathrm{kg}^{-1}$ (Skoglund, 2008). From the structures of various avenanthramides, presented in literature, in oats grain and husks ferulic, $p$-coumaric, caffeic acids occur in the highest concentrations, and to a lesser extent, sinapic acid, vanillic, syringic acid (Kováčová, Malinová, 2007; Mackevic, 2010; Gani et al., 2012). Ferulic and $p$-coumaric acids were found in the insoluble-bound fraction of all grain samples. The concentrations of other phenolic acids account for a smaller part of the total content of phenolic acid. In buckwheat grain and husks, hydroxybenzoic p-hydroxybenzoic and 3,4-dihydroxybenzoic - acids are additionally detected (Guo et al., 2011).

A wide range of products are currently being offered to consumers, therefore in order to balance nutrition it is recommended that a human body receives a daily portion of beneficial substances with foods that provide health benefits. The current study was aimed to determine total phenolic content and antioxidant activity, rutin, quercetin and phenolic acids content in buckwheat, husked and common oats, winter spelt, winter and spring wheat grain with or without husks or glume, only husks or glume as well as to estimate phenolic compounds ratio and to compare their distribution between cereal grain and husks and in this way to ascertain the losses of phenolic compounds in grain which will be used for food production.

\section{Material and methods}

Extraction and sample preparation. The raw cereal samples (1 kg) of buckwheat (cv. 'VB Vokiai'), husked oats (cv. 'Mina DS') and common oats (cv. 'Migla DS'), winter spelt wheat (cv. 'Frankencorn'), winter wheat (cv. 'Toras') and spring wheat (cv. 'Granary') grain with and without husks, only husks or glume were obtained from different regions (Pasvalys,
Šiauliai, Varena and Biržai) of Lithuania. Analysis of phenolic compounds (total and individual) was done at Institute of Agriculture, Lithuanian Research Centre for Agriculture and Forestry in 2013-2014. A total of 63 harvested samples (39 grain, 13 husks and 11 glume) were dried to a moisture content of about $8 \%$ (husks and glumes) $-15 \%$ (grain), then cleaned of dust and broken kernels. All samples were milled in an IKA A11 Basic Mill ("Staufen", Germany) and stored at $-20^{\circ} \mathrm{C}$ until analysis. Total phenolic content, rutin and quercetin in cereal samples were extracted by the method reported by Mikašauskaite et al. (2013) with a slight modification. Milled samples were accurately weighed $2.50 \mathrm{~g}$ and extracted with $25.0 \mathrm{~mL} 75 \%(\mathrm{v} / \mathrm{v})$ aqueous methanol at room $\left(21 \pm 1^{\circ} \mathrm{C}\right)$ temperature for $15 \mathrm{~h}$ in a shaker incubator Tu-400 (MRC, Israel) under constant shaking. The mixtures were centrifuged ("Hermle", Germany) for $10 \mathrm{~min}$ at $4000 \mathrm{rpm}$. The raw extracts were stored at $-20^{\circ} \mathrm{C}$ until use. Total phenolic acids contents were tested according to Kvasnička et al. (2008). One gram $( \pm 0.001 \mathrm{~g})$ of ground sample was weighed into a $100-\mathrm{ml}$ volumetric flask and $25 \mathrm{ml}$ of $0.1 \mathrm{M} \mathrm{NaOH}$ added. The slurry was shaken in a water bath WNB 14 ("Memmert", Germany) at $40^{\circ} \mathrm{C}$ for $60 \mathrm{~min}$, cooled to room temperature, acidified with $2 \mathrm{M} \mathrm{HCl}$ to $\mathrm{pH} 5-6$ (indicator paper) and $20 \mathrm{ml}$ of methanol was added. The flask was placed in an ultrasonic bath ("Bandelin Electronic", Germany) for 30 min, cooled to room temperature and made up to volume with methanol. The filtrate after filtration by $0.22 \mu \mathrm{m}$ membrane filter (Frisenette ApS, Denmark) was analysed by high performance liquid chromatography (HPLC).

Chemicals and reagents. All the chemicals were of analytical grade and were used as received. For extraction, methanol HPLC LiChrosolv ${ }^{\circledR}$, acetonitrile LiChrosolv ${ }^{\circledR}$ (MERCK, Germany) were used. Sodium carbonate, Folin-Ciocalteu reagent, 2,2-diphenyl-1-picrylhydrazyl (DPPH), 2,2'-Azinobis(3-ethylbenzothiazoline-6-sulfonic acid) diamonium salt (ABTS), potassium persulphate, phosphate-buffered saline (PBS), sodium acetate, acetic acid, sodium hydroxide, sodium sulphate anhydrous, hydrochloric acid and mix of seven phenolic acids ( $p$-hydroxybenzoic, 3,4-dihydroxybenzoic, $p$-coumaric, ferulic, vanillic, sinapic and syringic) standards were purchased ("SigmaAldrich", Germany). Deionized water with resistivity of $18.2 \mathrm{M} \Omega$ was generated by a Mili-Q plus system ("Milipore", USA).

Determination of total phenolic content. Total phenolic content of each extract was determined using the method described by Sedej et al. (2010) with some modifications. Briefly, $100 \mu \mathrm{L}$ extracts or control were mixed with $7.9 \mathrm{~mL}$ of distilled deionized water, followed by addition of $0.5 \mathrm{~mL}$ Folin-Ciocalteu reagent and then allowed to stand at room temperature for $6 \mathrm{~min}$. Next, $1.50 \mathrm{~mL} 20 \%$ aqueous sodium carbonate was added. The absorbance of solutions was measured at $760 \mathrm{~nm}$ using a UV/VIS spectrophotometer PerkinElmer LAMBDA 25 ("PerkinElmer", USA). The total phenolic content of the cereal grain and husks samples was expressed as $\mathrm{mg}$ of rutin eq. $\mathrm{g}^{-1}$ dry weight (d.w.). The concentration range of rutin was $0.05-1.5 \mathrm{mg} \mathrm{mL}^{-1}$. 
Determination of $\mathrm{DPPH}^{+}$and $\mathrm{ABTS}^{+}$radical scavenging activities. The methods described by Kaškoniene et al. (2015) for determination the $\mathrm{DPPH}^{+}$ and by Baltrušaityte et al. (2007) for determination the $\mathrm{ABTS}^{+}$radical scavenging activities were used to assess cereal grain and husks phenolics. The amount of $10 \mathrm{mg}$ of the $\mathrm{DPPH}^{+}$was dissolved in $250 \mathrm{~mL}$ of an acetonitrilemethanol $(1: 1, \mathrm{v} / \mathrm{v})$ solution and mixed with $250 \mathrm{~mL}$ of $0.1 \mathrm{M} \mathrm{pH} 5.5$ sodium acetate buffer. The volume of $77 \mu \mathrm{l}$ of the sample $\left(0.2 \mathrm{mg} \mathrm{ml}^{-1}\right)$ was added into $3000 \mu \mathrm{l}$ of $\mathrm{DPPH}^{+}$buffered solution $(0.50 \pm 0.04$ absorbance units (AU)) and left in the dark. The absorbency was read at room temperature after $15 \mathrm{~min}$ at $515 \mathrm{~nm}$. A blank sample was prepared using the corresponding sample preparation procedure replacing the cereal extracts with the same amount of $75 \%$ methanol. Stock solution of $2 \mathrm{mM}$ ABTS was prepared by dissolving in $50 \mathrm{ml}$ of PBS $\left(\mathrm{pH}\right.$ 7.4). The $\mathrm{ABTS}^{+}$was produced by reacting $50 \mathrm{ml}$ of stock solution with $200 \mathrm{ml}$ of $70 \mathrm{mM} \mathrm{K} \mathrm{S}_{2} \mathrm{O}_{8}$ water solution. The mixture was left to stand in the dark at room temperature for $15-16 \mathrm{~h}$ before use. Ten microliters of $6 \mu \mathrm{g} \mathrm{ml}^{-1}$ cereal samples extracts solution were mixed with $3 \mathrm{ml}$ of $\mathrm{ABTS}^{+}$solution $(0.80 \pm 0.02 \mathrm{AU})$ in the disposable $1 \mathrm{~cm}$ path length microcuvette. The absorbency was read at room temperature after $4 \mathrm{~min}$ at $734 \mathrm{~nm}$. PBS solution was used as a blank sample. The measurements were performed in triplicate. The antioxidant activity was calculated as follows: activity $(\%)=\left(A_{c}-A_{t} / A_{c}\right)$ $\times 100$, were $A_{t}$ is absorbance of samples, and $A_{c}$ is the absorbance of methanolic $\mathrm{DPPH}^{+}$and $\mathrm{ABTS}^{+}$solution. The absorbtion measurements were compared with the calibration curves of rutin solutions.

HPLC analysis for determination of phenolic acids, rutin and quercetin content. HPLC system was employed and consisted of the following modules: system controller SCL-10Avp, auto injector SIL-10ADvp, solvent delivery module LC-10ATvp, UV-Vis detector SPD-10AVvp, low pressure gradient flow control valve FCL-10ALvp, column oven CTO-10ACvp, on-line degasser DGU-14A. Data collection and evaluation was performed by using operating system LCsolution Workstation ("Shimadzu", Japan). Phenolic acids were separated by method described by Amarowicz and Weidner (2001) on LiChrospher 100 RP-18 column (250 $\times 4.6 \mathrm{~mm}, 5 \mu \mathrm{m})$ (“Alltech", USA). Column was protected with guard column Lichrosphere RP-18 $(7.5 \times 4.6 \mathrm{~mm})$ ("Alltech"). Phenolic acids were eluted with mobile phase consisting of water:acetonitrile:acetic acid (88:10:2, $\mathrm{v}: \mathrm{v}: \mathrm{v})$; flow rate $1 \mathrm{ml} \mathrm{min}^{-1}$; column temperature $30^{\circ} \mathrm{C}$; injection volume $10 \mu \mathrm{l}$. Absorbtion was measured on 260 and $320 \mathrm{~nm}$. Rutin and quercetin were separated by the method described by Fabjan et al. (2003). The injection volume was $10 \mu \mathrm{L}$. The components were detected by absorbance at $360 \mathrm{~nm}$. The mobile phase was solvent A (methanol) and solvent B (methanol:water:acetic acid, 100:150:5, v:v:v). The program of elution was $100 \%$ solvent $\mathrm{B}$ for the first $4 \mathrm{~min}$, followed by a linear gradient from $0 \%$ to $100 \%$ of solvent $\mathrm{A}$ in $15 \mathrm{~min}$, holding $100 \%$ (solvent A) for an additional $10 \mathrm{~min}$, and after all followed by stepwise decrease to $0 \%$ of solvent $\mathrm{A}$ in $0.5 \mathrm{~min}$ and holding $100 \%$ of solvent $B$ for additional $6.5 \mathrm{~min}$. The flow rate was $1.0 \mathrm{~mL} \mathrm{~min}^{-1}$.

Statistical analysis. Statistical analysis of total phenolic content, phenolic acids contents and antioxidant activity data was performed by mean \pm standard deviation (SD) of Microsoft Office Excel 2007 ("Microsoft", USA). The significance of differences $(P<0.05)$ between means was compared by Duncan's multiple range tests. Calculations were made using packages an ANOVA and STAT ENG from software SELEKCIJA (Tarakanovas, Raudonius, 2003).

\section{Results and discussion}

Total phenolic content and antioxidant activity of cereal samples. The total phenolic content and antioxidant activity of examined cereal samples are shown in Table 1. Total phenolic contents in examined cereal grain ranged: buckwheat with husks $>$ common oats $=$ spelt wheat $>$ husked oats $>$ common wheat $>$ common oats grain without husks. In respect to husks and glumes, the total phenolic contents hierarchy was as follows: buckwheat $>$ husked oats $>$ spelt wheat $>$ common oats. Two methods were used to test the antioxidant activity of cereal samples, which were complementary to some degree - a significant linear correlation $r=0.779$, when $P$ $<0.01$ was obtained. Both methods of antioxidant activity significantly correlated with total phenolic content. Correlation coefficients represented $r_{\mathrm{DPPH}}=0.864$ and $r_{\mathrm{ABTS}}=0.612(P<0.01)$.

Table 1. Total phenolic content and antioxidant activity of cereal samples

\begin{tabular}{|c|c|c|c|c|}
\hline \multirow{2}{*}{ Cereal } & \multirow{2}{*}{ Item } & \multirow{2}{*}{$\begin{array}{l}\text { Total phenolic content } \\
\mathrm{mg} \mathrm{g}^{-1} \text { dry weight }\end{array}$} & \multicolumn{2}{|c|}{ Antioxidant activity $\%$} \\
\hline & & & $\mathrm{DPPH}^{+}$ & $\mathrm{ABTS}^{+}$ \\
\hline \multirow{2}{*}{ Buckwheat } & grain with husks & $10.2 \mathrm{e} \pm 1.6$ & $44 d \pm 2$ & $60 d \pm 1$ \\
\hline & husks & $14.1 \mathrm{f} \pm 2.0$ & $70 \mathrm{e} \pm 3$ & 70 e \pm 6 \\
\hline \multirow{2}{*}{ Husked oats } & grain without husks & $1.8 \mathrm{abc} \pm 0.1$ & $13 b \pm 6$ & $41 \mathrm{c} \pm 2$ \\
\hline & husks & $2.6 \mathrm{ab} \pm 0.1$ & $24 \mathrm{c} \pm 6$ & $56 \mathrm{~d} \pm 4$ \\
\hline \multirow{2}{*}{ Common oats } & grain without husks & $2.8 \mathrm{a} \pm 1.1$ & $15 \mathrm{ab} \pm 2$ & $42 b c \pm 5$ \\
\hline & husks & $5.7 \mathrm{~d} \pm 1.1$ & $25 \mathrm{c} \pm 6$ & $59 \mathrm{~d} \pm 2$ \\
\hline \multirow{2}{*}{ Winter spelt wheat } & grain without glume & $3.5 \mathrm{bc} \pm 0.3$ & $8 a b \pm 2$ & $35 \mathrm{c} \pm 5$ \\
\hline & glume & $4.3 \mathrm{c} \pm 0.8$ & $20 \mathrm{c} \pm 6$ & $52 \mathrm{~d} \pm 11$ \\
\hline Winter wheat & grain without glume & $2.7 a b c \pm 0.3$ & $16 b \pm 1$ & $45 b c \pm 5$ \\
\hline Spring wheat & grain without glume & $3.8 \mathrm{bc} \pm 0.1$ & $8 a \pm 1$ & $30 \mathrm{a} \pm 1$ \\
\hline
\end{tabular}

Notes. Data expressed as means \pm standard deviations. Means in a column followed by the different lower case letter correspond to significant differences $(P<0.05)$. $\mathrm{DPPH}^{+}-2,2$-diphenyl-1-picrylhydrazyl radicals, $\mathrm{ABTS}^{+}-2,2^{\prime}$-Azino-bis (3-ethylbenzothiazoline6 -sulfonic acid) diamonium salt radicals. 
Our results showed that significantly highest total phenolic content and antioxidant activity were in cereal husks. Buckwheat husks and grain with husks contained 2-5 times more phenolic compounds and had 2-4 times higher antioxidant activity than oats and wheat samples (Table 1). For grain, buckwheat was followed by spring wheat and winter spelt wheat grain without glume, and the lowest phenolic compounds concentration was detected in common oats grain without husks. No significant differences were established between the samples of winter wheat, spring wheat without glume and husked oats grain without husks. The lowest antioxidant activity was in wheat grain without glume. In husks fraction, husked oats samples had total phenolic content $50 \%$ significantly higher than in common oats and $20 \%$ higher than in spelt wheat glume. Antioxidant activity followed by buckwheat husks was predominant in oats samples, but the differences between common, husked oats and spelt wheat husks were not significant.

Phenolic compounds with antioxidant activity in agricultural plants have been determined in several studies. Research evidence shows that according to total phenolic content and antioxidant activity in agricultural crops, buckwheat is of the most important plants. $\mathrm{Li}$ et al. (2013) reported that extract of buckwheat husks has significantly more phenolic compounds than buckwheat grain with husks. Buckwheat husks exhibited the highest antioxidant activity. Djordjevic et al. (2011) indicated that among four examined cereals, buckwheat had the highest amount of total phenolics with the highest DPPH radical scavenging activity. Lower total phenolic contents were found in wheat and barley, and the lowest in rye. Alvarez-Jubete et al. (2010) have reported that total phenolic content among the pseudocereal seed extracts differed greatly and was highest in buckwheat, followed by quinoa and amaranth $(P<0.01)$. Serpen et al. (2008) developed two procedures for the measurement of the antioxidant capacity of cereal grain from the market. Both methods show that the antioxidant capacity of buckwheat grain was higher than that of oats and wheat grain. Sedej et al. (2010) suggest that in buckwheat flour the content of phenolics and antioxidant activity are dozens of times higher than those in winter wheat flours. All presented authors' results indicate statistically significant relationships between total phenolic content and antioxidant activity. Thus, being abundant in bioactive phenolics, buckwheat is a valuable, healthbenefiting product.

Rutin and quercetin content in cereal samples. Strong antioxidant activity of buckwheat extracts might be attributed to the presence of polyphenols, especially rutin - one of the main antioxidative components in buckwheat (Balasundram et al., 2006; Zhang et al., 2012). Rutin content in buckwheat grain with husks distributed within a wide range: from 113.2 in husks to $406.3 \mu \mathrm{g}$ $\mathrm{g}^{-1}$ d.w. in grain with husks (Table 2). The correlation coefficients showed positive correlation between rutin and total phenolic contents $(r=0.670, P<0.01)$, as well as rutin and antioxidant activity of buckwheat grain with husks, respectively $r_{\mathrm{DPPH}}=0.900$ and $r_{\mathrm{ABTS}}$ $=0.824$, when $P<0.05$. Traces of rutin were found in spring wheat without glume and in spelt wheat husks. In separate cases, small rutin concentrations were detected in husked oats husks, and in the samples of oats grain without husks rutin was not detected at all. However, in oats quercetin concentration was up to 20 times higher than in buckwheat. The highest values of quercetin were found in husked oats samples. In buckwheat quercetin concentration ranged from $0.02 \%$ in grain with husks to $0.07 \%$ in husks from the total phenolic content, while husked oats samples had quercetin from $1.3 \%$ to $5 \%$. Common oats samples had up to $30 \%$ lower quercetin content than husked oats. No quercetin was detected in wheat samples.

Table 2. Rutin and quercetin contents analytical range ( $\mu \mathrm{g} \mathrm{g}^{-1}$ dry weight) in cereal samples

\begin{tabular}{|c|c|c|c|c|c|}
\hline Cereal & Item & Rutin & $\mathrm{CV} \%$ & Quercetin & $\mathrm{CV} \%$ \\
\hline \multirow{2}{*}{ Buckwheat } & grain with husks & $146.5-406.3$ & 39 & $3.1-6.71$ & 21 \\
\hline & husks & $113.2-139.8$ & 8 & $2.8-4.1$ & 9 \\
\hline \multirow{2}{*}{ Husked oats } & grain without husks & n.d. & & $24.0-89.0$ & 68 \\
\hline & husks & $0.00-30.2$ & 87 & $37.6-88.2$ & 41 \\
\hline \multirow{2}{*}{ Common oats } & grain without husks & n.d. & - & $12.2-51.6$ & 71 \\
\hline & husks & n.d. & - & $2.7-48.3$ & 117 \\
\hline \multirow{2}{*}{ Winter spelt wheat } & grain without glume & n.d. & - & n.d. & - \\
\hline & glume & $0.4-1.5$ & 33 & n.d. & - \\
\hline Winter wheat & grain without glume & n.d. & - & n.d. & - \\
\hline Spring wheat & grain without glume & $2.4-2.5$ & 1 & n.d. & - \\
\hline
\end{tabular}

$\mathrm{CV}$ - coefficient of variation; n.d. - not detected

Since no analyses of phenolic compounds contents in Lithuania-grown buckwheat, oats and wheat had been done before it was very interesting to compare our results with those obtained by other countries' researchers. However, no data were found on measured relatively high concentrations of quercetin in grain and husks of oats. Zielińska et al. (2010) indicated that buckwheat grain contains $0.043 \%$ of rutin in the aerial parts of common buckwheat plants and grains are a lesser source of rutin compared with buckwheat leaves and flowers. Some authors have reported that quercetin and rutin content in grain and husks depends on the variety, growing conditions and time of harvest (Fabjan et al., 2003; Guo et al., 2011; Tong et al., 2014). 
Flavonoids in plant cell are found more as free compounds than bound to cell wall, therefore rutin and quercetin bound form occurs only in small quantities. Research suggests that free phenolic compounds, such as rutin, quercetin have strong antifungal properties, and this is useful for a plant, since free phenolics are likely to be much more toxic to the invading organism than the bound forms (Lattanzio et al., 2006; Cabarkapa et al., 2008).

Phenolic acids content in cereal samples. Seven phenolic acids were quantified and identified in cereal samples: $p$-hydroxybenzoic and 3,4-dihydroxybenzoic acid (Table 3), $p$-coumaric, ferulic, vanillic, sinapic and syringic acid (Table 4). The results of the total content and percentage distribution of examined phenolic acids in cereal samples are given in Table 5. The total phenolic acids contents (sum of seven phenolic acids) in the cereal samples ranged from 882.4 to $83.4 \mu \mathrm{g} \mathrm{g}^{-1} \mathrm{~d}$.w. Phenolic acids concentration in buckwheat grain with husks ranged from $1.7 \mu \mathrm{g} \mathrm{g}^{-1} \mathrm{~d}$.w. vanillic acid to $44.6 \mu \mathrm{g} \mathrm{g}^{-1}$ d.w. 3,4-dihydroxybenzoic acid. Buckwheat husks range was similar but about $23 \%$ higher than in grain with husks (Table 3). 3,4-dihydroxybenzoic acid accounted for $72.8 \%$ of the total phenolic acid content in husks and $53.5 \%$ in grain with husks (Table 5 ). Whereas in winter spelt wheat significantly less 3,4-dihydroxybenzoic acid was established in single cases in husked oats husks and was not detected in all common oats samples. Lattanzio et al. (2006) suggest that this acid is very important for plants since it provides disease resistance.

Table 3. $p$-hydroxybenzoic $\left(p\right.$-HB) and 3,4-dihydroxybenzoic $(3,4-\mathrm{DHB})$ acids content $\left(\mu \mathrm{g} \mathrm{g}^{-1} \pm \mathrm{SD}\right.$ dry weight) in cereal samples

\begin{tabular}{llcc}
\hline \multicolumn{1}{c}{ Cereal } & \multicolumn{1}{c}{ Item } & $p$-HB & $3,4-\mathrm{DHB}$ \\
\hline \multirow{2}{*}{ Buckwheat } & grain with husks & $17.5 \mathrm{e} \pm 0.9$ & $44.6 \mathrm{~b} \pm 6.4$ \\
& husks & $10.8 \mathrm{~d} \pm 0.2$ & $102.6 \mathrm{c} \pm 1.9$ \\
\hline \multirow{2}{*}{ Husked oats } & grain without husks & $1.7 \mathrm{a} \pm 1.9$ & n.d. \\
& husks & $10.9 \mathrm{~d} \pm 2.6$ & $1.5 \mathrm{a} \pm 1.5$ \\
\hline \multirow{2}{*}{ Common oats } & grain without husks & n.d. & n.d. \\
& husks & $8.7 \mathrm{c} \pm 0.1$ & n.d. \\
\hline \multirow{2}{*}{ Winter spelt wheat } & grain without glume & $1.4 \mathrm{a} \pm 0.1$ & $8.1 \mathrm{a} \pm 3.6$ \\
& glume & $5.0 \mathrm{~b} \pm 0.4$ & $4.2 \mathrm{a} \pm 1.2$ \\
\hline Winter wheat & grain without glume & $1.4 \mathrm{a} \pm 0.1$ & $2.5 \mathrm{a} \pm 0.3$ \\
\hline Spring wheat & grain without glume & $0.9 \mathrm{a} \pm 0.0$ & n.d. \\
\hline
\end{tabular}

Notes. Data expressed as means \pm standard deviations (SD). Means in a column followed by the different lower case letter correspond to significant differences $(P<0.05)$; n.d. - not detected.

$p$-hydroxybenzoic acid predominated in buckwheat grain with husks and accounted for $21 \%$ of total examined phenolic acid content. In buckwheat husks it was similar to $p$-coumaric and ferulic acid: it accounted for $\sim 8 \%$ percentage distribution of total phenolic acids content. No significant differences in $p$-hydroxybenzoic acid content were determined between wheat and oats samples (Table 4). Buckwheat samples had positive correlation between vanillic and $p$-hydroxybenzoic acids content $(r=0.943, P<0.05)$. Of all the cereals tested, buckwheat had significantly least concentration of ferulic acid. Literature source indicates that as much as $98 \%$ of the ferulic acid exists in oats and wheat samples. Our results of ferulic and vanillic acids in buckwheat grain with husks and only husks are similar to those obtained by Kováčová and Malinová (2007), Guo et al. (2011) and Gani et al. (2012). However, the content of $p$-hydroxybenzoic, 3,4-dihydroxybenzoic, $p$-coumaric acids in buckwheat grown in Lithuania were several times higher in our studies. We did not find syringic acid in buckwheat samples but in bound form in buckwheat grain with husks it was identified by Alvarez-Jubete et al. (2010). Research has proved that vanillic acid, $p$-hydroxybenzoic acid and other phenolic

Table 4. Phenolic acid content ( $\mu \mathrm{g} \mathrm{g}^{-1}+\mathrm{SD}$ dry weight) in cereal samples

\begin{tabular}{|c|c|c|c|c|c|c|}
\hline \multirow{2}{*}{ Cereal } & \multirow{2}{*}{ Item } & \multicolumn{5}{|c|}{ Phenolic acids } \\
\hline & & $p$-coumaric & ferulic & vanillic & sinapic & syringic \\
\hline Buckwheat & $\begin{array}{l}\text { grain with husks } \\
\text { husks }\end{array}$ & $\begin{array}{c}8.2 \mathrm{a} \pm 1.4 \\
10.6 \mathrm{a} \pm 0.3\end{array}$ & $\begin{array}{c}4.7 \mathrm{a} \pm 1.2 \\
10.3 \mathrm{a} \pm 1.2\end{array}$ & $\begin{array}{l}1.7 \mathrm{a} \pm 0.3 \\
6.6 \mathrm{~b} \pm 3.5\end{array}$ & $\begin{array}{c}6.6 \mathrm{ab} \pm 1.0 \\
\text { n.d. }\end{array}$ & $\begin{array}{l}\text { n.d. } \\
\text { n.d. }\end{array}$ \\
\hline Husked oats & $\begin{array}{l}\text { grain without husks } \\
\text { husks }\end{array}$ & $\begin{array}{c}5.7 \mathrm{a} \pm 1.4 \\
269.9 \mathrm{c} \pm 23.1\end{array}$ & $\begin{array}{c}98.7 \mathrm{~b} \pm 9.4 \\
309.0 \mathrm{~d} \pm 19.0\end{array}$ & $\begin{array}{c}2.6 \mathrm{a} \pm 0.1 \\
11.2 \mathrm{~d} \pm 0.3 \\
\end{array}$ & $\begin{array}{c}24.00 \mathrm{cde} \pm 5.1 \\
1.4 \mathrm{a} \pm 0.8 \\
\end{array}$ & $\begin{array}{c}3.4 \mathrm{~cd} \pm 2.0 \\
6.8 \mathrm{~d} \pm 0.6 \\
\end{array}$ \\
\hline Common oats & $\begin{array}{l}\text { grain without husks } \\
\text { husks }\end{array}$ & $\begin{array}{c}11.3 \mathrm{a} \pm 0.1 \\
399.3 \mathrm{c} \pm 2.8\end{array}$ & $\begin{array}{l}105.0 \mathrm{~b} \pm 5.9 \\
458.5 \mathrm{f} \pm 1.4\end{array}$ & $\begin{array}{c}3.4 \mathrm{a} \pm 0.1 \\
8.9 \mathrm{bcd} \pm 0.0\end{array}$ & $\begin{array}{c}28.1 \mathrm{cde} \pm 0.0 \\
2.7 \mathrm{ab} \pm 0.0\end{array}$ & $\begin{array}{c}5.5 \mathrm{bcd} \pm 0.2 \\
4.3 \mathrm{~b} \pm 0.0\end{array}$ \\
\hline $\begin{array}{l}\text { Winter spelt } \\
\text { wheat }\end{array}$ & $\begin{array}{l}\text { grain without glume } \\
\text { glume }\end{array}$ & $\begin{array}{c}9.6 \mathrm{a} \pm 2.5 \\
159.4 \mathrm{~b} \pm 4.3\end{array}$ & $\begin{array}{c}283.5 \mathrm{~cd} \pm 19.6 \\
401.3 \mathrm{f} \pm 44.6\end{array}$ & $\begin{array}{c}2.6 \mathrm{a} \pm 0.3 \\
10.4 \mathrm{~cd} \pm 0.5\end{array}$ & 23.5 cde \pm 4.8 n.d. & $\begin{array}{c}0.3 \mathrm{a} \pm 0.2 \\
5.6 \mathrm{bcd} \pm 7.2\end{array}$ \\
\hline Winter wheat & grain without glume & $6.0 \mathrm{a} \pm 0.1$ & $266.2 \mathrm{~cd} \pm 8.8$ & $2.6 \mathrm{a} \pm 0.4$ & $35.2 \mathrm{e} \pm 0.5$ & $4.41 \mathrm{~b} \pm 0.8$ \\
\hline Spring wheat & grain without glume & $7.1 \mathrm{a} \pm 0.9$ & $244.3 \mathrm{c} \pm 14.2$ & $2.5 \mathrm{a} \pm 0.5$ & $17.8 \mathrm{bc} \pm 2.3$ & n.d. \\
\hline
\end{tabular}

Notes. Data expressed as means \pm standard deviations (SD). Means in a column followed by the different lower case letter correspond to significant differences $(P<0.05)$; n.d. - not detected. 
acids are characterised by antifungal effect against some of microscopic fungi which produce mycotoxins toxic to living organisms (Lattanzio et al., 2006).

Phenolic acids contents quantified in common oats grain without husks were six times less $\left(153.28 \mu \mathrm{g} \mathrm{g}^{-1}\right.$ d.w.) than those in husks and ranged from $3.4 \mu \mathrm{g} \mathrm{g}^{-1} \mathrm{~d}$.w. vanillic acid to $105.0 \mu \mathrm{g} \mathrm{g}^{-1} \mathrm{~d}$.w. ferulic acid. Common oats husks had the significant highest total seven phenolic acids content $-882.4 \mu \mathrm{g} \mathrm{g} \mathrm{g}^{-1} \mathrm{~d}$.w. In husked oats grain without husks phenolic acids concentration ranged from $1.7 \mu \mathrm{g} \mathrm{g}^{-1} \mathrm{~d}$.w. $p$-hydroxybenzoic to $98.7 \mu \mathrm{g} \mathrm{g}^{-1} \mathrm{~d}$.w. ferulic acid. Sinapic acid accounted for $18 \%$ of the total phenolic content in husked and common oats grain without husks when in husks its concentration was significantly less. No significant differences were found between total phenolic acids of common oats and husked oats grain without husks. Ferulic acid was significantly predominant in all oats samples and accounted for $\sim 70 \%$ of total phenolic acids content. Ferulic and $p$-coumaric acid content showed positive correlation in all oats samples $(r=0.821, P<0.05)$ and together accounted for $96 \%$ of total phenolic acid content in oats husks samples. Vanillic, sinapic and syringic acids accounted for the remaining $4 \%$. It is noteworthy that these acids belong to the only oats specific group of avenanthramides, which have gained an increasing interest because they are known as potent antioxidants.

Our results agree with those obtained by Kováčová and Malinová (2007), where they also established correlations between the contents of ferulic and $p$-coumaric acids. It has been noted that oats antioxidative activity results are related to ferulic and $p$-coumaric acids synergetic action, but a stronger antioxidant is ferulic acid. Avenanthramides are heat-stable during processing and long-term storage does not affect the concentrations significantly (Skoglund, 2008; Teixeira et al., 2013). In contrast, storage of wheat flour results in marked loss of phenolic acids: after 6 months' storage flours contained the same phenolic acids in qualitative terms, but their concentrations were $70 \%$ lower. Cold storage, did not affect the content of polyphenols (Manach et al., 2004).

Results of winter spelt wheat samples show that total contents of seven phenolic acids in winter spelt wheat glume were one of the highest of all cereal samples $583.56 \mu \mathrm{g} \mathrm{g}^{-1} \mathrm{~d}$.w., followed by common and husked oats husks (Table 5). Significantly predominant ferulic acid and in separate cases significantly higher contents were established in wheat than in oats. Ferulic acid content in wheat grain without glume accounted for about $84-90 \%$ of total phenolic acids content. Winter spelt wheat had higher phenolic acids content than winter and spring wheat, but the differences were not significant. In contrast, strong correlation was obtained, where correlation coefficient $r$ $=0.998, P<0.01$. Furthermore, phenolic acids contents were similar to those in the samples of oats grain without husks. According to Manach et al. (2004), ferulic acid is found chiefly in the outer parts of the grain and $98 \%$ of the total ferulic acid contains the aleurone layer and the pericarp of wheat grain. Gani et al. (2012) indicate that total ferulic acid content among the tested grains was higher in wheat than in oats samples and could be used as a marker of wheat antioxidants. Hydroxycinnamic acids are bioavailable and can be absorbed by humans to a high degree and they can undergo extensive metabolism in the human digestive tract (Skoglung, 2008).

Table 5. The total content $\left(\mu \mathrm{g} \mathrm{g}^{-1}+\mathrm{SD}\right.$ dry weight) and percentage distribution of seven examined phenolic acids in cereal samples

\begin{tabular}{|c|c|c|c|c|c|c|c|c|c|}
\hline \multirow[b]{2}{*}{ Cereal } & \multirow[b]{2}{*}{ Item } & \multicolumn{8}{|c|}{ Phenolic acids } \\
\hline & & $\begin{array}{c}\sum \text { of } \\
\text { phenolic acids }\end{array}$ & $p$-coumaric & ferulic & vanillic & sinapic & $p$-HB & $3,4-\mathrm{DHB}$ & syringic \\
\hline \multirow{2}{*}{ Buckwheat } & grain with husks & $83.4 \mathrm{a} \pm 6.5$ & 9.8 & 5.6 & 2.0 & 8.0 & 21.0 & 53.5 & n.d. \\
\hline & husks & $140.9 \mathrm{ab} \pm 1.0$ & 7.5 & 7.3 & 4.7 & n.d & 7.7 & 72.8 & n.d. \\
\hline \multirow{2}{*}{ Husked oats } & grain without husks & $136.1 \mathrm{ab} \pm 4.3$ & 4.2 & 72.5 & 1.9 & 17.6 & 1.2 & n.d. & 2.5 \\
\hline & husks & $601.6 \mathrm{~d} \pm 9.3$ & 44.9 & 51.4 & 1.9 & 0.2 & 1.8 & 0.2 & 1.1 \\
\hline \multirow{2}{*}{ Common oats } & grain without husks & $153.3 \mathrm{abc} \pm 8.3$ & 7.3 & 68.5 & 2.2 & 18.3 & n.d. & n.d. & 3.6 \\
\hline & husks & $882.4 \mathrm{e} \pm 1.9$ & 45.2 & 52.0 & 1.0 & 0.3 & 1.0 & n.d. & 0.5 \\
\hline \multirow{2}{*}{$\begin{array}{l}\text { Winter spelt } \\
\text { wheat }\end{array}$} & grain without glume & $329.4 b c \pm 8.3$ & 2.9 & 86.1 & 1.8 & 7.1 & 0.4 & 2.6 & 0.1 \\
\hline & glume & $583.6 \mathrm{~d} \pm 74.8$ & 27.3 & 68.8 & 0.8 & n.d & 0.6 & 0.6 & 1.0 \\
\hline Winter wheat & grain without glume & $318.3 \mathrm{c} \pm 3.5$ & 1.9 & 83.6 & 0.8 & 11.0 & 0.4 & 0.8 & 1.4 \\
\hline Spring wheat & grain without glume & $272.4 b c \pm 16.2$ & 2.6 & 89.7 & 0.9 & 6.5 & 0.3 & n.d. & n.d. \\
\hline
\end{tabular}

Notes. Data of sum of phenolic acids expressed as means \pm standard deviations (SD). Means in a column followed by the different lower case letter correspond to significant differences $(P<0.05)$. $p$-HB $-p$-hydroxybenzoic acid, 3,4-DHB - 3,4-dihydroxybenzoic acid; n.d. - not detected.

The study revealed a trend that sinapic acid dominates only in cereal grain, and husks contain significantly less of this acid or do not contain it at all. Therefore, husks or glume contain significantly higher (3 times) concentrations of vanillic acid as well as other phenolic acids than cereal grain without husks or glume. Reports on the antioxidant activity of hydroxycinnamic acids suggest that sinapic acid generally has the highest activity, followed by ferulic and $p$-coumaric acid (Skoglung, 2008). There are data indicating that sinapic acid has protective effect against myocardial infarct, also anti-inflammatory and neuro-protective effect (Roy, Prince, 2012). Thus, considering the composition of valuable food components, it is important that this acid is not lost during grain de-hulling process. Having analysed all groups of cereal samples it was confirmed that buckwheat phenolics (total phenolic content, rutin, quercetin concentration) exist predominantly in the free form and wheat and oat phenolics (phenolic acid) exist primarily in the bound with cell wall forms. Research suggests that free phenolics may be digested in the upper gastrointestinal tract, while bound phenolics may reach the colon and exert their 
health benefits (Guo et al., 2011). Significantly higher amounts of quercetin in oats than in other tested cereals show oats to be of higher nutritional value.

\section{Conclusions}

1. The significantly highest total phenolic content, antioxidant activity and rutin content of all cereal samples (grain with and without husks or glume and only husks or glume) were determined for buckwheat. In grain with husks, rutin content was higher than in husks. Of the phenolic acids, in buckwheat significantly predominant were hydroxybenzoic acids: 3,4-dihydroxybenzoic acid was predominant in all buckwheat samples, and the content of $p$-dihydrobenzoic acid was significantly highest in buckwheat grain with husks.

2. Oats samples were distinguished from other cereals tested by the highest quercetin content, which was significantly predominant in husked oats samples. Common oats samples, especially husks, had the significantly highest total seven phenolic acids content. Ferulic acid and $p$-coumaric acid predominanted and showed positive correlation in all oats husks samples. Except for both hydroxybenzoic acids, common oats had higher phenolic acids contents than husked oats samples.

3. Spelt wheat grain without glume had higher total seven phenolic acids content than winter and spring wheat grain without husks. However, the differences were not significant and regression analysis showed the correlation between the examined phenolic acids contents in winter spelt, winter and spring wheat grain without glume $(r=0.998, P<0.01)$. Ferulic acid content was most important in wheat samples and in separate cases its contents were higher than in oats.

4. Cereal grain had significantly higher sinapic acid content than husks or glume. In contrast, vanillic acid, hydroxybenzoic acids, $p$-coumaric and ferulic acids concentrations were higher in examined cereal husks or glume than in grain.

5. Significantly higher total phenolic content, antioxidant activity, total seven examined phenolic acids contents were in cereal husks than in cereal grain. Higher content of phenolic compounds in husks can protect cereals from toxicological and microbiological contamination therefore our further research is focused on antifungal activity of phenolic compounds in cereals against microscopic fungi and mycotoxins produced by them.

\section{Acknowledgements}

The study was supported by the Research Council of Lithuania, Project No. SVE-04/2014.

Received 06052015

Accepted 31072015

\section{References}

Alvarez-Jubete L., WijngaardH.,ArendtE.K., GallagherE. 2010 Polyphenol composition and in vitro antioxidant activity of amaranth, quinoa buckwheat and wheat as affected by sprouting and baking. Food Chemistry, 119: 770-778 http://dx.doi.org/10.1016/j.foodchem.2009.07.032

Amarowicz R., Weidner S. 2001. Content of phenolic acids in rye caryopses determined using DAD-HPLC method. Czech Journal of Food Science, 19: 201-205
Balasundram N., Sundram K., Samman S. 2006. Phenolic compounds in plants and agri-industrial by-products: antioxidant activity, occurrence, and potential uses: analytical, nutritional and clinical methods. Food Chemistry, 99: 191-203 http://dx.doi.org/10.1016/j.foodchem.2005.07.042

Baltrušaitytė V., Venskutonis P. R., Ceksterytė V. 2007. Radical scavenging activity of different floral origin honey and beebread phenolic extracts. Food Chemistry, 101: 502-514 http://dx.doi.org/10.1016/j.foodchem.2006.02.007

Biel W., Bobko K., Maciorowski R. 2009. Chemical composition and nutritive value of husked and naked oats grain. Journal of Cereal Science, 49: 413-418 http://dx.doi.org/10.1016/j.jcs.2009.01.009

Čabarkapa I. S., Sedej I. J., Sakač M. B., Ljubiša Ć. Šarić L. Ć. Dragana V., Plavšić D. V. 2008. Antimicrobial activity of buckwheat (Fagopyrum esculentum Moench) husks extracts. Food Processing, Quality and Safety, 35: 159-163

Dietrych-Szóstak D. 2004. Flavonoids in husks of different varieties of buckwheat and their antioxidant activity. Proceedings of the $9^{\text {th }}$ International Symposium on Buckwheat. Prague, Czech Republic, p. 621-625

Djordjevic T. M., Šiler-Marinkovic S. S., DimitrijevicBrankovic S. I. 2011. Antioxidant activity and total phenolic content in some cereals and legumes. International Journal of Food Properties, 14: 175-184 http://dx.doi.org/10.1080/10942910903160364

Fabjan N., Rode J., Košir I. J., Wang Z., Zhang Z., Kreft I. 2003. Tartary buckwheat (Fagopyrum tataricum Gaertn.) as a source of dietary rutin and quercitrin. Journal of Agricultural and Food Chemistry, 51: 6452-6455 http://dx.doi.org/10.1021/jf034543e

Gani A., Wani S. M., Masoodi F. A., Hameed G. 2012. Wholegrain cereal bioactive compounds and their health benefits: a review. Journal of Food Processing and Technology, 3: 1-10 http://dx.doi.org/10.4172/2157-7110.1000146

Guo X. D., Ma Y. J., 1, Parry J., Gao J. M., Yu L. L., Wang M. 2011. Phenolics content and antioxidant activity of tartary buckwheat from different locations. Molecules, 16: 9850 $9867 \mathrm{http}: / / \mathrm{dx}$.doi.org/10.3390/molecules 16129850

Jablonskytė-Raščè D., Maikštėnienè S., Mankevičienė A. 2013. Evaluation of productivity and quality of common wheat (Triticum aestivum L.) and spelt (Triticum spelta L.) in relation to nutrition conditions. Zemdirbyste-Agriculture, 100 (1): 45-56 http://dx.doi.org/10.13080/z-a.2013.100.007

Kaškonienė V., Kaškonas P., Maruška A. 2015. Volatile compounds composition and antioxidant activity of bee pollen collected in Lithuania. Chemical Papers, 69: 291-299 http://dx.doi.org/10.1515/chempap-2015-0033

Kováčová M., Malinová E. 2007. Ferulic and coumaric acids, total phenolic compounds and their correlation in selected oat genotypes. Czech Journal of Food Science, 25: 325-332

Kvasnička F., Čopiková J., Ševčik R., Krátká J., Syntytsia A., Voldřich M. 2008. Determination of phenolic acids by capillary zone electrophoresis and HPLC. Central European Journal of Chemistry, 6: 410-418 http://dx.doi.org/10.2478/s11532-008-0032-5

Lattanzio V., Lattanzio V. M., Cardinali A. 2006. Role of phenolics in the resistance mechanisms of plants against fungal pathogens and insects. Phytochemistry: Advances in Research, 661: 23-67

Li F. H., Ya Y. U. A. N., Yang X. L., Tao S. Y, Jian M. I. N. G. 2013. Phenolic profiles and antioxidant activity of buckwheat (Fagopyrum esculentum Möench and Fagopyrum tartaricum L. Gaerth) husks, brans and flours. Journal of Integrative Agriculture, 12: 1684-1693 http://dx.doi.org/10.1016/S2095-3119(13)60371-8

Mackevic A. 2010. The effect of different $\mathrm{pH}$ during steeping on avenanthramide content in germinated oats. Swedish University of Agricultural Sciences, Uppsala, Sweden, 17 p. 
Manach C., Scalbert A., Morand Ch., Rémésy Ch., Jiménez L. 2004. Polyphenols: food sources and bioavailability. The American Journal of Clinical Nutrition, 79: 727-747

Mikašauskaitė J., Ragažinskienė O., Maruška A. 2013. Variation of total amount of phenolic compounds, radical scavenging activity and volatile compounds of Liriodendron tulipifera L. and Ginkgo biloba L. leaves extracts during different vegetation periods. Biologiia, 59: 175-186 http://dx.doi.org/10.6001/biologija.v59i2.2750

Roy S. J., Prince P. S. M. 2012. Protective effects of sinapic acid on lysosomal dysfunction in isoproterenol induced myocardial infarcted rats. Food and Chemical Toxicology, 50: 3984-3989 http://dx.doi.org/10.1016/j.fct.2012.08.017

Sedej I. J., Sakač M. B., Mišan A. C., Mandić A. I. 2010. Antioxidant activity of wheat and buckwheat flours. Matica Srpska Journal of Natural Sciences, 118: 59-68 http://dx.doi.org/10.2298/ZMSPN1018059S

Serpen A., Gökmen V., Pellegrini N., Fogliano V. 2008. Direct measurement of the total antioxidant capacity of cereal products. Journal of Cereal Science, 48: 816-820 http://dx.doi.org/10.1016/j.jcs.2008.06.002

Skoglund M. 2008. Phenolic compounds in oats: dissertation. Swedish University of Agricultural Sciences, Uppsala, Sweden, $52 \mathrm{p}$.

Sytar O. 2014. Phenolic acids in the inflorescences of different varieties of buckwheat and their antioxidant activity. Journal of King Saud University Science, 27 (2): 136-142 http://dx.doi.org/10.1016/j.jksus.2014.07.001
Tarakanovas P., Raudonius S. 2003. Agronominių tyrimų duomenu statistine analize taikant kompiuterines programas $A N O V A$, STAT, SPLIT-PLOT iš paketo SELEKCIJA ir IRRISTAT. Lithuanian University of Agriculture, 58 p. (in Lithuanian)

Teixeira J., Gaspar A., Garrido E. M., Garrido J., Borges F. 2013. Hydroxycinnamic acid antioxidants: an electrochemical overview. BioMed Research International, 2013: 1-11 http://dx.doi.org/10.1155/2013/251754

Tong L. T., Liu L. Y., Zhong K., Yan W. A. N. G., Guo L. N., Zhou S. M. 2014. Effects of cultivar on phenolic content and antioxidant activity of naked oat in China. Journal of Integrative Agriculture. 13: 1809-1816 http://dx.doi.org/10.1016/S2095-3119(13)60626-7

Vojtíšková P., Kmentová K., Kubáň V., Kráčmar S. 2012. Chemical composition of buckwheat plant (Fagopyrum esculentum) and selected buckwheat products. Journal of Microbiology, Biotechnology and Food Sciences, 1: 1011-1019

Zhang Z. L., Zhou M. L., Tang Y., Li F. L., Tang Y. X., ShaoJ. R., Xue W. T., Wu Y. M. 2012. Bioactive compounds in functional buckwheat food. Food Research International,49: 389-395 http://dx.doi.org/10.1016/j.foodres.2012.07.035

Zielińska D., Szawara-Nowak D., Zieliński H. 2010. Determination of the antioxidant activity of rutin and its contribution to the antioxidant capacity of diversified buckwheat origin material by updated analytical strategies. Polish Journal of Food and Nutrition Sciences, 60: 315-321

ISSN 1392-3196 / e-ISSN 2335-8947

Zemdirbyste-Agriculture, vol. 102, No. 3 (2015), p. 289-296

DOI 10.13080/z-a.2015.102.037

\title{
Biologiškai aktyvūs fenoliniai junginiai grikiuose, avižose ir žieminiuose spelta kviečiuose
}

\author{
I. Kerienè ${ }^{1}$, A. Mankevičienè ${ }^{1}$, S. Bliznikas ${ }^{2}$, D. Jablonskytè-Raščè ${ }^{1}, S$. Maikštėnienè ${ }^{1}$, \\ R. Česnulevičiené ${ }^{1}$
}

${ }^{1}$ Lietuvos agrarinių ir miškų mokslų centras

${ }^{2}$ Lietuvos sveikatos mokslų universiteto Gyvulininkystès institutas

\section{Santrauka}

Tyrimo tikslas - nustatyti grikių, avižų, kviečių grūduose ir jų lukštuose arba vapažvyniuose bendrą fenolių kiekị, jų antioksidacinị aktyvumą, rutino, kvercetino, fenolinių rūgščių koncentracijas, ịvertinti fenolinių junginių pasiskirstymą juose ir išsiaiškinti, kiek bioaktyvių junginių prarandama maisto gamybai skirtuose grūduose, lyginant su lukštais arba vapažvyniais. Bendras fenolių kiekis ir antioksidacinis aktyvumas nustatyti taikant spektrofotometinị metodą, o individualūs fenoliniai junginiai kiekybiškai ịvertinti efektyviosios skysčių chromatografijos metodu.

Išanalizavus visų javų grupių mėginius nustatyta, kad reikšmingai $(P<0,05)$ didžiausias bendras fenolių kiekis $\left(10,2 \pm 1,6 \mathrm{mg} \mathrm{g}^{-1}\right.$ sausujų medžiagų (s. m.) nelukštentuose grūduose ir $14,1 \pm 2,0 \mathrm{mg} \mathrm{g}^{-1} \mathrm{~s}$. m. lukštuose), antioksidacinis aktyvumas (2-4 kartus), rutino koncentracija (nuo 146,5 iki 406,3 $\mu \mathrm{g} \mathrm{g}^{-1} \mathrm{~s}$. m.) ir su nedidelèmis išimtimis hidroksibenzoinių rūgščiu koncentracijos buvo grikiuose. Avižų grūdai arba lukštai pasižymėjo dideliu kiekiu kvercetino. Belukščių avižų grūduose arba lukštuose kvercetino nustatyta reikšmingai daugiau $(\sim 31-89 \mu \mathrm{g}$ $\mathrm{g}^{-1}$ s. m.). Paprastųjų avižų lukštai iš kitų javų reikšmingai išsiskyre didžiausiu suminiu fenolinių rūgščių kiekiu $-882,4 \pm 1,9 \mu \mathrm{g} \mathrm{g}^{-1} \mathrm{~s}$. m. Avižų bei kviečių grūduose ir lukštuose arba varpažvyniuose reikšmingai $(P<0,01)$ dominavo ferulo bei $p$-kumaro rūgštys ir sudarè 70-90 \% analizuotų fenolinių rūgščių kiekio. Syringo rūgštis būdinga spelta žieminių, žieminių kviečių bei avižų grūdams ir lukštams. Tyrimo metu nustatyta, kad sinapo rūgštis dominavo tik javų grūduose, o vanilino, $p$-hidroksibenzoinès, 3,4-dihidroksibenzoinès, $p$-kumaro, ferulo rūgšties koncentracijos, bendras fenolių kiekis, antioksidacinis aktyvumas buvo reikšmingai didesnis lukštuose arba varpažvyniuose nei grūduose.

Reikšminiai žodžiai: fenolinès rūgštys, grūdai, kvercetinas, lukštai, rutinas. 